\title{
PENGARUH PENGAMBILAN KEPUTUSAN TERHADAP ASUHAN KEPERAWATAN
}

\section{Ria Oktaviany}

Email : riariaok29@gmail.com

\begin{abstract}
Abstrak
Latar Belakang : Di dalam kehidupan manusia tentu tak lepas dari permasalahan yang menuntut untuk dilakukan pengambilan keputusan. Hal ini juga tidak berbeda dengan perawatan di rumah sakit. Baik perawat, tenaga kesehatan, klien, dan keluarga dituntut untuk mengambil keputusan di waktu dan juga kondisi yang tepat. Keputusan dalam penyelesaian masalah merupakan kemampuan mendasar bagi tenaga kesehatan, khususnya dalam asuhan keperawatan. Metode : Metode yang digunakan untuk menemukan pengaruh pengambilan keputusan terhadap asuhan keperawatan adalah dengan menggunakan kajian pustaka. Hasil : Berdasarkan hasil literasi dapat disimpulkan bahwa pengambilan kelutusan yang tepat berpengaruh pada tingkat kualitas asuhan keperawatan. Pengambilan keputusan sangat penting keberadaannya baik dalam asuhan maupun dalam manajemen keperawatan. Pembahasan : Asuhan keperawatan adalah pelayanan serta tindakan yang dilakukan oleh perawat guna mencapi kesembuhan klien dan memandirikan klien agar mampu meningkatkan kesejahteraan kesehatannya. Dalam memberikan asuhan keperawatan terdapat sebuah proses yang dikenal sebagai proses keperawatan. Penutup : Pengambilan keputusan sangat penting dalam menentukan asuhan keperawatan yang tepat kepada pasien.
\end{abstract}

\section{Latar Belakang}

Di dalam kehidupan manusia tentu tak lepas dari permasalahan yang menuntut untuk dilakukan pengambilan keputusan. Hal ini juga tidak berbeda dengan perawatan di rumah sakit. Baik perawat, tenaga kesehatan, klien, dan keluarga dituntut untuk mengambil keputusan di waktu dan juga kondisi yang tepat. Keputusan dalam penyelesaian masalah merupakan kemampuan mendasar bagi tenaga kesehatan, khususnya dalam asuhan keperawatan. Tidak hanya berpengaruh pada proses pengelolaan asuhan keperawatan, tetapi penting untuk 
meningkatkan kemampuan merencanakan perubahan. Perawat pada semua tingkatan posisi klinis harus memiliki kemampuan menyelesaikan masalah dan mengambil keputusan yang efektif, baik sebagai pelaksana/staf maupun sebagai pemimpin. Kemampuan membuat keputusan masalah etis menjadi salah satu persyaratan bagi perawat dalam menjalankan praktik keperawatan professional. Pengambilan keputusan merupakan suatu pendekatan sistematis dalam menyelesaikan suatu masalah.

Pengambilan keputusan sangat penting dalam menentukan asuhan keperawatan yang tepat kepada pasien. Cristine W. Nibbelink, 2017 mengatakan bahwa perawat harus mempertimbangkan banyak faktor yang berpotensi mempengaruhi proses pengambilan keputusan dalam memenuhi kebutuhan pasien. Perawat harus mempunyai kemampuan yang baik untuk pasien atau untuk dirinya didalam menghadapi masalah yang menyangkut etika. Tidak hanya perawat, setiap orang yang turut berperan dalam perawatan klien harus berpikir secara rasional, bukan emosional dalam membuat keputusan etis. Keputusan yang dimaksud membutuhkan keterampilan berpikir secara sadar yang diperlukan untuk menyelamatkan keputusan klien dan memberikan asuhan. Haryono, 2012 menegaskan bahwa kemampuan membuat keputusan masalah etis menjadi salah satu persyaratan bagi perawat untuk menjalankan praktik keperawatan professional. Pengambilan keputusan yang tepat ini sangat berpengaruh terhadap tingkat asuhan keperawatan karena jika dalam pengambilan keputusan tidak tepat maka asuhan keperawatan yang dilakukan juga tidak efektif dan efisien.

\section{Metode}

Metode yang digunakan untuk menemukan pengaruh pengambilan keputusan terhadap asuhan keperawatan adalah dengan menggunakan kajian pustaka. Maksud metode kajian pustaka disini adalah penulis mengumpulkan berbagai sumber literatur yang memiliki keterkaitan dengan topik yang dibahas ini. Penulis mengandalkan hasil penelitian dari beberapa jurnal, skripsi, ebook, dan beberapa karya ilmiah lain yang relevan dengan topik yang diambil penukis. Setelah dikumpulkan, karya-karya ilmiah tadi akan dianalisis serta dikaji satu per satu untuk mendapatkan jawaban dari pengaruh pengambilan keputusan terhadap asuhan keperawatan

\section{Hasil}


Berdasarkan hasil literasi dapat disimpulkan bahwa pengambilan kelutusan yang tepat berpengaruh pada tingkat kualitas asuhan keperawatan. Salah satu contoh pengambilan keputusan yang dilakukan perawat adalah penentuan diagnosa keperawatan. Jika keputusan yang ditentukan tepat maka tentu asuhan keperawatan yang diberikan akan efektif dan berpengaruh positif terhadap kesembuhan klien. Penilaian dan keputusan klinis dibutuhkan untuk mendapatkan kualitas pelayanan yang optimal. Pemberian asuhan dan pelayanan keperawatan harus berdasarkan nilai-nilai dan etika yang dianut oleh klien dan nilai-nilai profesional asuhan keperawatan.

Ennis 1996 menyatakan keputusan klinis adalah proses yang meliputi diagnosis klinis, penilaian dan keputusan tentang apa yang harus dilakukan. Dianan Catarina. 2009, Jan Florin. 2007, Mehee, juaga menyimpulkan proses pengambilan keputusan dalam praktik klinik keperawatan dipahami sebagai serangkaian keputusan yang dibuat oleh perawat dalam interaksinya dengan pasien mengenai jenis pengamatan yang akan dilakukan dalam situasi yang di alami klien (pengkajian keperawatan), perumusan diagnosa keperawatan, rencana tindakan keperawatan yang harus diambil, tindakan keperawatan yang akan diambil serta evaluasi.

Pengambilan keputusan sangat penting keberadaannya baik dalam asuhan maupun dalam manajemen keperawatan. Pengambilan keputusan oleh perawat dilakukan dengan mempertimbangkan beberapa pilihan terbaik yang paling tepat dengan kondisi klien. Dalam pengambilan keputusan seorang perawat dituntut mampu memahami klien sehingga keputusan yang diambil tidak bertolak belakang dengan keinginan serta kebutuhan klien. Dengan pemahaman tersebut tentunya asuhan keperawatan dan pelayanan yang diberikan oleh perawat memperoleh keluasan dari pasien. Kepuasan klien merupakan salah satu indikator keberhasilan asuhan keperawatan.

Dalam mengambil sebuah keputusan guna memberikan asuhan keperawatan yang tepat ada beberapa hal yang harus diperhatikan perawat. Dalam mengambil sebuah keputusan perawat harus mampu berpikir kritis, kolaborasi perawat klien dan keluarga, dan memahami prinsip moral dan etik diri sendiri serta klien. Dalam menyusun proses keperawatan diperlukan pengambilan keputusan yang tepat oleh perawat dalam setiap tahapannya.

\section{Pembahasan}


Asuhan keperawatan adalah pelayanan serta tindakan yang dilakukan oleh perawat guna mencapi kesembuhan klien dan memandirikan klien agar mampu meningkatkan kesejahteraan kesehatannya. Dalam memberikan asuhan keperawatan terdapat sebuah proses yang dikenal sebagai proses keperawatan. Proses keperawatan merupakan suatu panduan untuk memberikan asuhan keperawatan profesional, untuk individu, kelompok, keluarga dan komunitas, berdasarkan prinsip ilmiah dan melalui suatu tahapan-tahapan, yaitu; pengkajian, diagnosa keperawatan, rencana intervensi/tindakan, implementasi/tindakan dan evaluasi. Dalam setiap proses keperawatan terkandung beberapa keputusan yang diambil oleh perawat dan juga klien. Keputusan yang tepat dalam proses keperawatan tentunya akan menghasilkan asuhan keperawatan yang tepat pula.

Setiadi (2012) mengatakan bahwa dalam melakukan pengkajian keperawatan harus secara aktif menanyakan keluhan yang dialami dan perawat juga harus mendengarkan penuh dengan perhatian dan perasaan terhadap setiap apa yang dikatakan pasien. Tahap pengkajian ini harus dilakukan secara kritis sehingga tidak ada informasi penting yang tertinggal karena tidak ditanyakan. Pada tahap pengkajian, perawat juga telah mengambil keputusan. Terkait pertanyaan yang dibutuhkan untuk menentukan asuhan keperawatan perawat harus memutuskan apakah hal tersebut harus ditanyakan, apakah hal tersebut akan menyingung perasaan klien, atau apakah hal tersebut tidak semestinya ditanyakan. Pengambilan keputusan terkait pengkajian ini dilakukan berdasarkan tingkat pengetahuan serta pengalaman perawat tentang keluhan yang dialami oleh klien.

Diagnosis keperawatan merupakan hasil penilaian perawat dengan melibatkan pasien dan keluarga terkait pengkajian yang telah dilakukannya. Proses penentuan diagnosa pasien ini harus tepat dengan cara melibatkan pasien dan beberapa pihak berupaya untuk menvalidasi, memperkuat dan menentukan prioritas masalah pasien dengan benar. Dalam penentuan diagnosa keperawatan perawat harus mengambil keputusan yang tepat yang sesuai dengan kebutuhan klien. Penentuan keputusan diagnosa yang tepat akan berdampak pada proses lainnya yang juga berpengaruh terhadap kualitas asuhan keperawatan yang akan dilakukan. Bila perawat mengambil keputusan dignosa yang tepat maka lama perawatan klien akan bertambah dimana hal tersebut tentunya bukan hal yang diinginkn serta dibutuhkan klien. 
Tahap rencana keperawatan merupakan penyusunan rencana tindakan keperawatan yang akan dilakukan perawat untuk menangani masalah pasien sesuai dengan diagnosa keperawatan. Rencana keperawatan yang disusun perawat harus berdasarkan pengetahuan tentang asuhan keperawatan dan masalah terkait kesehatan klien. Penyusunan rencana keperawatan ini penting agar dalam pelaksanaan asuhan, perawat tidak bingung dan tidak memiliki dasar yang jelas dalam tindakannya.

Pada saat akan melakukan implementasi, perawat kontrak waktu dengan pasien dan menyampaikan serta menjelaskan apa yang akan dilakukan, tahapan-tahapan serta tujuan tindakan. Pengambilan keputusan disini harus dipikirkan perawat secara kritis, apakah implementasi yang dilakukannya berguna untuk kesehatan klien dan apakah implementasinya akan sesuai dengan apa yang diharapkan perawat, klien, serta keluarga.

Pada tahap evaluasi, perawat memutuskan apakah tindakan keperawatan yang dilakukannya ini memiliki feedback positif dari klien atau tidak. Tahap ini juga menyadarkan perawat tentang kekurangan dalam asuhan keperawatannya.

Ada lima hal yang perlu diperhatikan dalam pengambilan keputusan, diantaranya :

- Dalam proses pengambilan keputusan tidak terjadi secara kebetulan melainkan dengan penuh pertimbangan.

- Pengambilan keputusan tidak dilakukan secara sembrono tapi harus berdasarkan pada sistematika tertentu:

- Tersedianya sumber-sumber untuk melaksanakan keputusan yang akan diambil.

○ Kualifikasi tenaga kerja yang tersedia

- Falsafah yang dianut organisasi.

○ Situasi lingkungan internal dan eksternal yang akan mempengaruhi administrasi dan manajemen di dalam organisasi.

- Masalah harus diketahui dengan jelas.

- Pemecahan masalah harus didasarkan pada fakta-fakta yang terkumpul dengan sistematis.

- Keputusan yang baik adalah keputusan yang telah dipilih dari berbagai alternatif yang telah dianalisa secara matang. 
Ketepatan pengambilan keputusan perawat akan di pengaruhi oleh kompentisi perawat, kemampuan berkomunikasi, lingkungan serta budaya. Penting bagi perawat untuk selalu meningkatkan kapasitas dirinya sebagai profesi dalam pemberian asuhan keperawatan. Hal ini akan meningkatkan kepercayaan masyarakat terhadap perawat yang selanjutnya akan meningkatkan profesionalisme perawat. Pengambilan keputusan yang tepat akan meningkatkan kemandirian klien dalam asuhannya serta membantu klien untu menentukan pilihan bantuan yang tepat sesuai dengan kondisi yang dialami klien.

Tahapan dalam pengambilan keputusan harus didasari hal-hal berikut, yaitu :

\section{- Berpikir Kritis}

Berpikir kritis digambarkan sebagai sikap yang memikirkan "sebuah proses, tujuan untuk membuat keputusan yang masuk akal tentang apa yang harus percaya dan apa yang harus dilakukan". Pengambilan keputusan klinis adalah sebuah proses yang melibatkan nalaran diagnostik dan penilaian klinis klien. Pemecahan masalah dan pengambilan keputusan yang efektif diprediksi bahwa individu harus memiliki kemampuan berpikir kritis dan mengembangkan dirinya dengan adanya bimbingan dan role model di lingkungan keperawatan atau rumah sakit.Dalam mengambil senuah keputusan perawat harus mampu berpikir secara kritis tentang apakah keputusan ini yang diinginkan dan dibutuhkan klien, apakah keputusan yang akan diambil memiliki tujuan yang jelas, dan apakah keputusan tersebut berdampak baik pada klien dan kelurga atau tidak.

- Kolaborasi Perawat-Klien-Keluarga

Dalam pengambilan keputusan, perawat harus memerhatikan hak-hak klien dimana klien berhak memutuskan perawatan apa yang akan dijalaninya. Tentunya tidak hanya bergantung pada klien, tapi keputusan klien akan dipertimbangkan kembali apakah keoutusan tersebut selaras dengan keputusan perawat dan apakah keputusan tersebut berguna untuk perawatan klien di rumah sakit. Apabila klien tidak mampu menyuarakan keputusannya, maka didiskusikan dengan pihak yang memiliki kewenangn terhadap klien baik di depan hukum maupun secara ikatan persaudaraan. Pengalaman keluarga dalam pengambilan keputusan tindakan medis, tindakan keperawatan dan pengobatan diputuskan dari semua anggota keluarga klien yang ada. Keputusan keluarga diambil dengan cara diskusi dengan pihak yang bersangkutan dengn klien. 
- Memahami prinsip moral dan etik pribadi serta klien

Perawat harus mengembangkan keterampilan untuk melaksanakan peran dan fungsinya sebagai perantara moral dan sebagai partisipan dalam pengambilan keputusan yang Moralitas berhubungan dengan apa yang benar dan salah. Perawat juga harus memahami apakah keputusan tersebut sesuai dengan moral, etik, dan agama klien atau tidak.

Keputusan yang baik seharusnya tidak menentang prinsip moralitas dan agama klien.

Beberapa karakteristik seorang pengambil keputusan klinis yang baik adalah mampu menemukan pola dari setiap situasi klinis yang dihadapi, mampu menginterpretasikan setiap keluhan dan tanda gejala dari pasien, dan menggunakan intuisi yang terlatih karena mempunyai pengalaman kerja yang banyak. Sebagai seorang perawat perlu membahas masalah yang menyangkut pasien, memberikan solusi untuk keluhan dan perasaan yang diungkapkan oleh pasien dan menyelesaikan masalah dengan segera.Apabila perawat mengambil keputusan yang tepat maka tentu saja asuhan keperawatan yang dilakukan perawat akan berkualitas, efektif, dan sesuai dengan apa yang dibutuhkan klien. Apabila keputusan yang diambil perawat sesuai dengn keinginan serta kebutuhan pasien maka pasien akan merasa puas terhadap tindakan dan asuhan yang diberikan.

\section{Penutup}

Asuhan keperawatan adalah pelayanan serta tindakan yang dilakukan oleh perawat guna mencapi kesembuhan klien dan memandirikan klien agar mampu meningkatkan kesejahteraan kesehatannya. Apabila perawat mengambil keputusan yang tepat maka tentu saja asuhan keperawatan yang dilakukan perawat akan berkualitas, efektif, dan sesuai dengan apa yang dibutuhkan klien. Jika keputusan yang diambil perawat sesuai dengn keinginan serta kebutuhan pasien maka pasien akan merasa puas terhadap tindakan dan asuhan yang diberikan. Pengambilan keputusan sangat penting dalam menentukan asuhan keperawatan yang tepat kepada pasien. 


\section{Daftar Pustaka}

Aeni, W, N., Winani., Sutioso, H. (2019). Perilaku Caring Perawat dalam Memberikan Asuhan Keperawatan di Salah Satu RS di Kabupaten Indramayu. Jurnal Keperawatan Profesional (JKP), 7(2), p-ISSN: 2355-679X; e-ISSN: 2685-1830.

Budiono. (2016). Konsep Dasar Keperawatan. Jakarta : Pusdik SDM Kesehatan.

Deniati, K., Anugrahwati, R., Suminarti, T. (2018). Pengaruh Berpikir Kritis Terhadap Kemmpuan Perawat Pelaksana dalam Melakukan Asuhan Keperawatan di Rumah Sakit Hermina Bekasi Tahun 2016. Jurnal Kesehatan Holistik (The Journal of Holistic Healthcare), 12(1), 21-25.

Hafifah, I., Fithriyah, N. (2018). Pengalaman Keluarga dalam Pengambilan Keputusan pda Pasien Kritis di Ruanh Intensive Care Unit (ICU) RSUD Ulin Banjrmasin. Duni Keperawatan, 6(1), 11-18.

Khairina, I., Malini, H., Huriani, E. (2018). Faktor-faktor yang Berhubungan dengan Pengambilan Keputusan Perawat dalam Ketepatan Triase di Kota Padang. Indonesian Journal of Health Science, 2(1), 1-6.

Ngesti, W, Utami. (2016). Etika Keperawatan dan Keperawatan Profesional. Jakarta : Pusdik SDM Kesehatan.

Pashar, Imran., Dwiantoro, Lucky. (2020). Pengaruh Empowerment Terhadap Pengambilan Keputusan Perawat: Kajian Literature Review. Journal of Holistic Nursing Science, 7(2), 124-132.

Purwati, E, I, I., Nuryadi., Herawati, Y, T. (2017). Pengambilan Keputusan dalam Pelaksanaan Rujukan Puskesmas sebagai Fasilitas Kesehatan Tingkat Pertama. e-Jurnal Pustaka Kesehatan, 5(2), 231-238.

Rahayu, C, D., Mulyani, Sri. (2020). Pengambilan Keputusan Klinis Perawat. Jurnal Ilmiah Kesehatan, 1-11.

Simamora, R. H. (2019). Menjadi perawat yang: CIH'HUY. Surakarta: Kekata Publisher. 
Simamora, R. H. (2005). Hubungan Persepsi Perawat Pelaksana Terhadap Penerapan Fungsi Pengorganisasian Yang Dilakukan Oleh Kepala Ruangan Dengan Kinerjanya Diruang Rawat Inap RSUD Koja Jakarta Utara (Doctoral dissertation, Tesis FIK UI, Tidak dipublikasikan).

Sudono, B., Setya, D., Atiningtyas, H. (2017). Gambaran Kemampuan Berpikir Kritis Perawat Primer dalam Pelaksanaan Asuhan Keperawatan di Rumah Sakit Islam Surakarta. Jurnal Ilmu Keperawatan Indonesia, 10(1), 79-106. 